\title{
Response of soybean and corn to soil mechanical intervention and agricultural gypsum application to the soil surface ${ }^{1}$
}

\section{Resposta da soja e milho a intervenção mecânica do solo e aplicação de gesso agrícola em superfície}

\author{
Lucindo Somavilla ${ }^{2}$; Marlo Adriano Bison Pinto ${ }^{2 *}$; Claudir José Basso \\ Clovis Orlando Da Ros ${ }^{3}$; Vanderlei Rodrigues da Silva ${ }^{3}$; \\ Thiarles Brun'; Antônio Luis Santi ${ }^{5}$
}

\begin{abstract}
Agricultural gypsum is considered an important tool in the improvement of soil chemical properties; however, crop responses to its application are contradictory. Studies have shown that the physical effects of soil mechanical intervention is short-lasting and has little impact on grain yield. Therefore, the aim of this study was to investigate corn and soybean response to soil mechanical interventions and to the application of agricultural gypsum to soil surface. The experiment involved cultivation of two crops each of soybean (i. e., 2009/2010 and 2011/2012 crop years) and corn (i. e., 2010/2011 and 2012/2013 crop years) with application of agricultural gypsum $\left(0,2,4\right.$ and $\left.6 \mathrm{Mg} \mathrm{ha}^{-1}\right)$ to the soil surface during the winter of 2009, after 12 years under continuous no-tillage system and two types of mechanical intervention: chisel plowing and plowing+harrowing. Soybean responded to mechanical interventions conducted in an area under continuous no-tillage system, but showed an increase of only $10 \%$ (114 $\mathrm{kg} \mathrm{ha}^{-1}$ ) in the grain yield with the use of agricultural gypsum in the 2011/2012 crop year. Gypsum caused a higher increase in the grain yield of corn than that of soybean. Moreover, the crop response to gypsum application varied considerably in the 2010/2011 crop year after mechanical interventions under continuous no-tillage cultivation.
\end{abstract}

Key words: Glycinemax (L), no-tillage system, yield, Zea mays

\section{Resumo}

O gesso agrícola tem sido apontado como importante ferramenta para a melhoria do perfil químico do solo, porém, as respostas das culturas, especificamente as de grãos são contraditórias. Para as intervenções mecânicas de solo, os resultados existentes revelam efeito físico pouco duradouro e com pouco impacto sobre o rendimento de grãos. Por isso, o objetivo do trabalho foi verificar as respostas do milho e da soja a intervenções mecânicas do solo e aplicação de gesso agrícola em superfície. O experimento consistiu no cultivo de duas safras de grãos de soja (2009/2010 e 2011/2012) e duas de

\footnotetext{
${ }^{1}$ Parte da Dissertação de Mestrado do primeiro autor, apresentada ao Programa de Pós-Graduação em Agronomia: Agricultura e Ambiente, Universidade Federal de Santa Maria, UFSM, Frederico Westphalen, RS, Brasil.

${ }^{2}$ Eng $^{\text {os }}$ Agr $^{\text {os }}$, Discentes de Mestrado em Agronomia: Agricultura e Ambiente, UFSM, Frederico Westphalen, RS, Brasil. Bolsista CNPq. E-mail: lucindosomavilla@hotmail com; marlo.bison@gmail.com

${ }^{3}$ Eng $^{\text {os }}$ Agros, Profs. Drs., Dept ${ }^{\circ}$ de Ciências Agronômicas e Ambientais, UFSM, Frederico Westphalen, RS, Brasil. E-mail: claudirbasso@gmail.com; clovisdaros@gmail.com; vanderlei@ufsm.br

${ }^{4}$ Eng $^{\circ}$ Agr $^{\circ}$, Discente de Mestrado em Engenharia Agrícola, UFSM, Santa Maria, RS, Brasil. Bolsista CAPES. E-mail: brun. thiarles@gmail.com

${ }^{5}$ Eng $^{\circ}$ Agr $^{\circ}$, Prof. Dr., Dept ${ }^{\circ}$ de Ciências Agronômicas e Ambientais, UFSM, Frederico Westphalen, RS, Brasil. Bolsista de produtividade em pesquisa do CNPq. E-mail: santi_pratica@yahoo.com.br

* Author for correspondence
} 
milho (2010/2011 e 2012/2013), com aplicação de gesso agrícola (0; 2; 4 e $\left.6 \mathrm{Mg} \mathrm{ha}^{-1}\right)$ em superfície no período invernal de 2009, após 12 anos de plantio direto contínuo e após dois tipos de intervenções mecânicas: (escarificação e aração+gradagem). Os resultados mostraram que a soja responde a intervenções mecânicas realizadas em área de plantio direto contínuo e, o incremento no rendimento de grãos com o uso de gesso agrícola foi de apenas 10\% (114 $\left.\mathrm{kg} \mathrm{ha}^{-1}\right)$ e somente na safra 2011/2012. Na cultura do milho houve maior incremento no rendimento de grãos com as doses de gesso em relação à soja e com variação na resposta ao gesso na safra 2010/2011 com as intervenções mecânicas aplicadas no plantio direto contínuo.

Palavras-chave: Glycine $\max (\mathrm{L})$, sistema plantio direto, produtividade, Zea mays

\section{Introduction}

In recent years, there has been non-compliance with the precepts of the no-tillage system (NTS). This has led to the formation of a compacted subsurface layer that restricts water infiltration and root system development, with a negative impact on the yields of major grain crops (COLLARES et al., 2008; NEIS et al., 2010). In addition to these physical constraints, a fertility gradient is formed and nutrients concentrate on the soil surface (NEIS et al., 2010; SCHLINDWEIN et al., 2013), which limits their absorption by plants, especially during droughts.

Mechanical interventions, such as plowing and chisel plowing, are often necessary to mitigate these problems. Although these alternative tools have a short-term physical effect (DRESCHER et al., 2011), they have an immediate response. With the aim of improving the fertility gradient, Meda et al. (2002) reported three methods to promote the movement of cations down the soil profile: mechanical incorporation, organic chemical mobilization, and inorganic chemical mobilization. The latter refers to the use of neutral salts such as agricultural gypsum.

Agricultural gypsum has been used as a tool to improvesoil chemical properties, either by increasing $\mathrm{Ca}^{2+}$ and $\mathrm{S}-\mathrm{SO}_{4}{ }^{2-}$ contents and the $\mathrm{Ca}^{2+} / \mathrm{Mg}^{2+}$ ratio in the soil (MASCHIETTO, 2009; RAMPIM et al., 2011; SOUZA et al., 2012; TRINDADE, 2013) or by altering the toxic aluminum forms in the soil subsurface (RAMPIM et al., 2011). These amendments lead to increased plant height
(CUSTÓDIO et al., 2005; SOUZA et al., 2010), increased production of dry matter (CUSTÓDIO et al., 2005; SORATTO; CRUSCIOL, 2008), higher nutrient absorption efficiency (CAIRES et al., 2006; CUSTÓDIO et al., 2005; RAMPIM et al., 2011), and consequently, better grain quality (CAIRES et al., 2006). The results of previous studies are contradictory with regard to grain yield (CAIRES et al., 2006; MASCHIETTO, 2009; NEIS et al., 2010; RAMPIM et al., 2011; SORATTO et al., 2010). Farmers in Médio Alto Uruguai in Rio Grande do Sul are of the opinion that agricultural gypsum, which has been used without technical support under the region's climate and soil conditions, is necessary and effective in the cultivation of major grain crops (soybean and corn).

Therefore, the hypothesis underlying this study is that mechanical intervention and the addition of gypsum to the soil surface improves the soil profile and has a positive effect on plant growth and yield. The study aimed to investigate corn and soybean responses to soil mechanical intervention combined with the addition of gypsum to the soil surface.

\section{Materials and Methods}

The experiment was conducted from July 2009 to February 2013 in a commercial farm in the municipality of Jaboticaba - RS, located at $27^{\circ} 40^{\prime} 29$. $03^{\prime \prime} \mathrm{S}$ and $53^{\circ} 17^{\prime} 51.28^{\prime \prime} \mathrm{W}$. The climate is humid subtropical (Cfa) according to the Köppen climate classification (MORENO, 1961). Rainfall patterns during the period of crop development are shown in Figure 1. The soil is characterized as dystrophic 
red latosol (EMBRAPA, 2013) or Rhodic Hapludox (SOIL SURVEY STAFF, 2010). It was managed under NTS for 12 years, mainly with wheat, soybean, and corn crops and without limits for the physical attributes of the soil's profile (BERTOLLO, 2014). The following physical and chemical properties were quantified in the $0.00-0.10 \mathrm{~m}$ layer before the start of the experiment: $698 \mathrm{~g} \mathrm{~kg}^{-1}$ of clay; $28 \mathrm{~g} \mathrm{~kg}^{-1}$ of organic matter; $\mathrm{pH}_{\text {(water 1:1) }} 5.8 ; \mathrm{CEC}_{\text {potential }}$ of 10 . $8 \mathrm{cmol}_{\mathrm{c}} \mathrm{dm}^{-3} ; 4.4$ and $2.4 \mathrm{cmol}_{\mathrm{c}} \mathrm{dm}^{-3}$ of exchangeable calcium and magnesium, respectively; 11. 9 and $175.3 \mathrm{mg} \mathrm{dm}^{-3}$ of exchangeable phosphorus and potassium(Mehlich-1), respectively, and11. $3 \mathrm{mg}$ $\mathrm{dm}^{-3}$ of sulfur extracted with calcium phosphate.

Figure 1. Daily rainfall during crops of soybean(2009/2010crop year) (A), corn(2010/2011crop year) (B), soybean(2011/2012crop year) (C), and corn(2012/2013crop year) (D). Frederico Westphalen, RS.

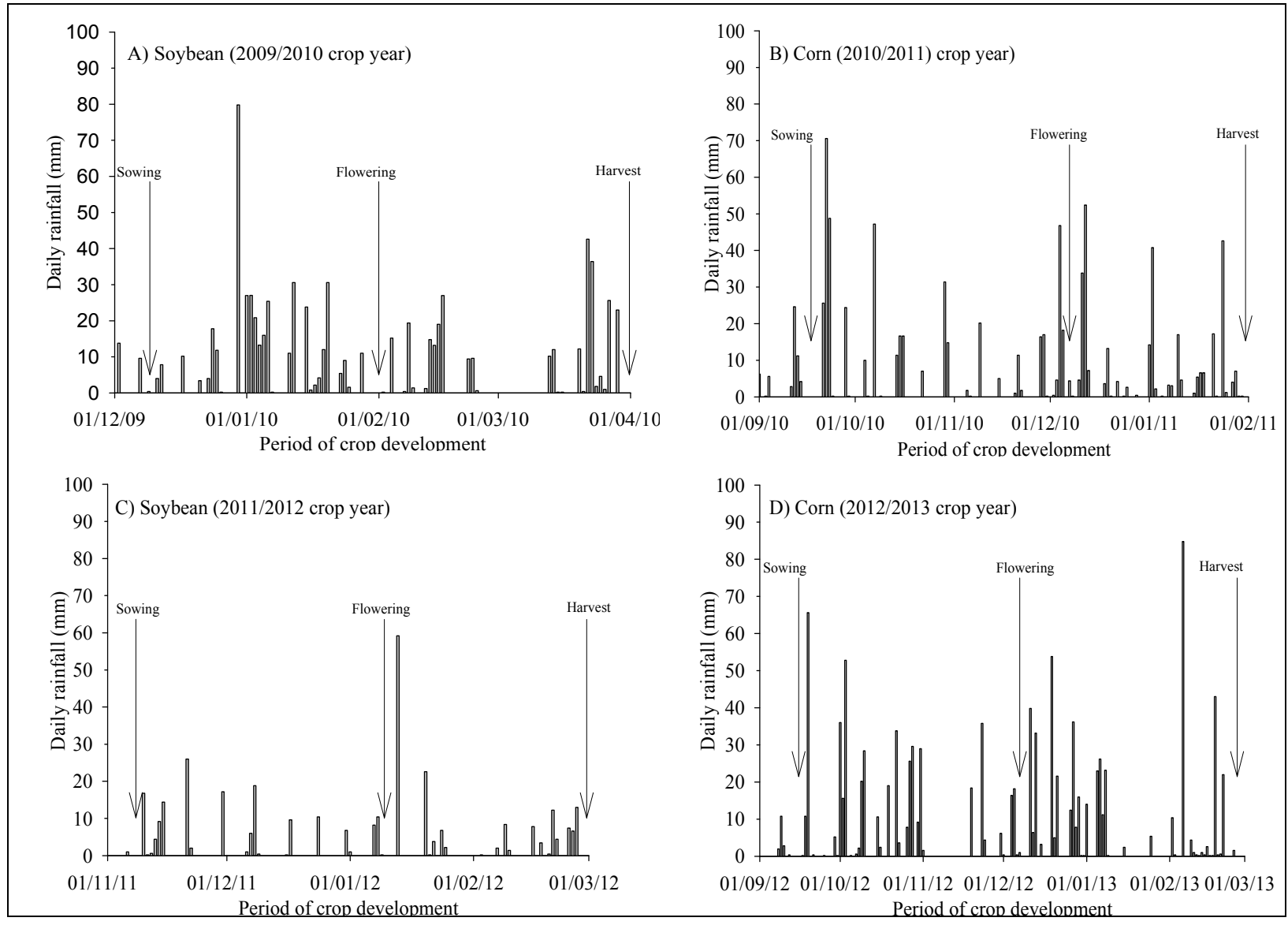

A randomized block experimental design was used, with four repetitions in a scheme of subdivided plots. The main plots $(5 \times 20 \mathrm{~m})$ were subjected to three modes of mechanical intervention: continuous NTS, chisel plowing, and plowing+harrowing; these soil management procedures were only performed at the start of the experiment (June 2009). Four doses of agricultural gypsum $\left(0,2,4\right.$, and $\left.6 \mathrm{Mg} \mathrm{ha}^{-1}\right)$ were broad casted in the subplots $(5 \times 5 \mathrm{~m})$ after soil management procedures (incorporation of white oat to cover the soil). Subsequently, successive crops of soybean/black oat/corn/wheat/soybean/corn were cultivated.

The first soybean crop (2009/2010crop year) was shown on 7 December 2009 using the "Fundacep $53{ }^{\circledR}$ RR" cultivar. The number of viable seeds used 
was 13.5 per linear meter and a spacing of 0.45 $\mathrm{m}$ between rows, with the final population being 300,000 plants per hectare. The second soybean crop (2011/2012 crop year) was shown on 7 November 2011 using the "BMX Energia ${ }^{\circledR} R R$ " cultivar. Plant density was 11 viable seeds per linear meter and a spacing of $0.45 \mathrm{~m}$ between rows to create a final population of 244,444 plants per hectare. Fertilization was performed with $45 \mathrm{~kg} \mathrm{ha}^{-1}$ of $\mathrm{P}_{2} \mathrm{O}_{5}$ (simple superphosphate) in the sowing line and 60 $\mathrm{kg} \mathrm{ha}^{-1}$ of $\mathrm{K}_{2} \mathrm{O}$ (potassium oxide) by broadcasting.

Plant height (PH), height of pod insertion (HPi), number of pods per plant (PP), and number of grains per plant (GP) were determined during physiological maturation using 10 random plants per plot. Plants from a work in area of $5.4 \mathrm{~m}^{2}$ in the center of the plot were collected by hand to determine yield, and mechanical threshing was subsequently performed with tractor equipment. Weight was adjusted to $13 \%$ moisture.

The first corn crop (2010/2011crop year) was performed using hybrid " $2 \mathrm{~A} 550^{\circledR}$ " with Herculex ${ }^{\circledR}$ I technology. Sowing was performed on 15 September 2010 at a density of 2.9 seeds per linear meter and a spacing of $0.45 \mathrm{~m}$ between rows, with the final population being 65,000 plants per hectare. The base fertilization was performed with $350 \mathrm{~kg}$ $\mathrm{ha}^{-1}$ of commercial formulation 09-25-15 (NPK), and surface fertilization was performed with 175 $\mathrm{kg} \mathrm{ha}^{-1}$ of nitrogen $(\mathrm{N})$ via urea at the V6 stage and in a single application. Sowing of the second corn crop (2012/2013) occurred on 14 September 2012 usinghybrid“AS1656 ${ }^{\circledR}$ " with VT Pro $2^{\mathrm{TM}_{\text {technology. }}}$ Plant density was 70,000 plants per hectare with a distribution of 3.15 plants per linear meter and a spacing of $0.45 \mathrm{~m}$ between rows. Base fertilization consisted of $400 \mathrm{~kg} \mathrm{ha}^{-1}$ ofcommercial formulation (NPK) 10-20-10 and surface fertilization consisted of two applications (V4 and V6) of $150 \mathrm{~kg} \mathrm{ha}^{-1}$ of N via urea.

The physiological maturation evaluation included plant height (PH) and height of ear insertion (HEi) of random plants in the plot. Yield was estimated using the mean weight of grains from ears collected in a $5.4 \mathrm{~m}^{2}$ working area in the center of each plot and moisture was adjusted to $13 \%$. Thousand-seed weight (TSW) was estimated using the mean weight of four repetitions of 100 units.

The results were subject to variance analysis using the $F$ test $(p<0.05)$ and analysis of simple effects within each combination of factors was performed when interactions were significant. The means of the qualitative treatments were compared using Tukey's test $(p<0.05)$, and the polynomial regression model was applied to the quantitative treatments using the GENES software (CRUZ, 2006).

\section{Results and Discussion}

No significant effects of the interaction was observed between the mechanical interventions and gypsum doses on the analyzed variables in either the first (2009/2010) or the second (2011/2012) soybean crops (first and third years of the experiment, respectively) (Figure 2A). However, grain yield was affected by gypsum doses in the second crop year. This lack of a positive response of the remaining variables of yield components to gypsum has been reported by several authors, including Souza et al. (2010). The lack of a soybean response to the addition of gypsum in the first crop may have occurred because of the short time of reaction in the soil (4 months), which was shorter than that in the second crop performed 28 months after gypsum application (Figure 2A). In fact, a similar explanation was provided by Trindade (2013) in a study with successive corn and soybean crops to which up to $8 \mathrm{Mg} \mathrm{ha}^{-1}$ of gypsum was added to the soil surface in a dystrophic red latosol soil under NTS. On the other hand, low rain fall during the second soybean crop (Figure 1C) probably favored the positive effect of gypsum, as was also described by Soratto and Crusciol (2008) in an assessment of nutrient accumulation in the aerial part of black oat. 
Figure 2. Soybean grain yield (2009/2010 and 2011/2012 crop years) (A) and corn grain yield (2010/2011crop year)foreach soil mechanical intervention andcorn grain yield (2012/2013 crop year) forthe mean of mechanical interventions according to gypsum dose (B). Frederico Westphalen, RS, 2014.

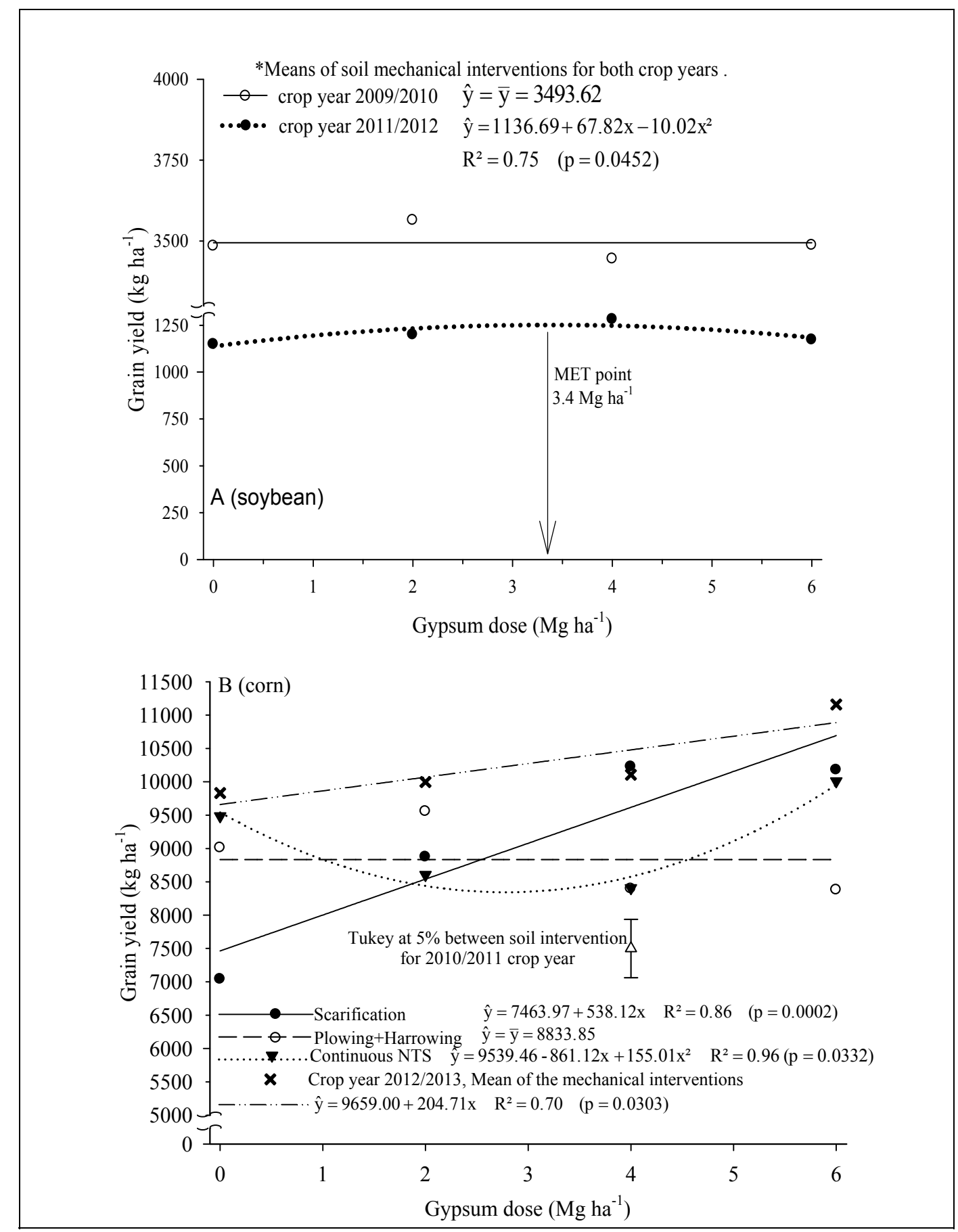

The lack of a response of soybean to soil mechanical intervention is probably related to the rainfall that occurred during the first crop (Figure 1A) and to the short-lasting physical effect of the mechanical interventions during the second crop(28 months), as reported by Drescher et al. (2011). Adequate humidity levels provide the soil with resilience to control aeration, temperature, 
and mechanical resistance. These physical factors interact and regulate root growth because they influence the soil's capacity to promote adequate conditions for plant growth and development, which affects crop growth and yield (COLLARES et al., 2006). Moreover, adequate soil physical quality in the experimental area, as described by Bertollo (2014), reduces the probability of an effect on grain yield (COLLARES et al., 2008).

Soybean grain yield in the second crop exhibited a quadratic response according to gypsum dose, with an increase of $114 \mathrm{~kg} \mathrm{ha}^{-1} \mathrm{up}$ to a dose of 3.4 $\mathrm{Mg} \mathrm{ha}^{-1}$ (Figure 2A). This may be associated with the uptake of sulfur because this element plays an important role in crop nutrition as a constituent of essential amino acids (cysteine and methionine) and of several coenzymes (MODA et al., 2013). Sulfur deficiency impairs protein synthesis and causes a reduction in yield (EPSTEIN; BLOOM, 2006). In addition, Caires et al. (2006) observed that gypsum can be used to improve the quality of seeds, although in other studies it has been reported to be associated with a lack of grain yield response in soybean crops (SOUZA et al., 2010; RAMPIM et al., 2011; TRINDADE, 2013).

In the first corn crop (2010/2011), there was a significant effect of the interaction between the various mechanical interventions and gypsum dose on yield and thousand-seed weight (Figure 2B). In the second crop (2012/2013), there was a difference in the height of ear insertion and grain yield according to gypsum dose only. However, a complementary analysis using regression showed that there was no difference in the height of ear insertion.

Corn grain yield data showed no response to gypsum in the plowing+harrowing treatment (Figure 2B). This is probably due to the inversion and mixing of soil layers caused by the disc plow and the formation of a superficial soil layer that is chemically poorer and whose fertility would be difficult to restore at 14 months after the procedure.
The treatment with gypsum (up to a minimum dose of $2.8 \mathrm{Mg} \mathrm{ha}^{-1}$ ) and without mechanical intervention (continuous NTS) resulted in a $12.5 \%$ (1. $194 \mathrm{~kg} \mathrm{ha}^{-1}$ ) reduction ingrain yield relative to a zero dose of gypsum (Figure 2B). This is probably associated with problems in the absorption of other nutrients, as stated by Custódio et al. (2005), who reported lower concentrations (curve inflection point) of nitrogen, potassium, iron, zinc, and copper in the leaves of Tanzania grass (Gramineae) when a similar dose of gypsum was administrated.

Corn grain yield and TSW were described by a mathematical first-degree model only when gypsum doses were applied after chisel plowing. The increase in grain yield was 7. $\%$ (534 $\left.\mathrm{kg} \mathrm{ha}^{-1}\right)$ for every $\mathrm{Mg} \mathrm{ha}^{-1}$ of added gypsum, according to the angular coefficient of the linear equation $(p=0$. 0002) (Figure 2B). The linear increase in TSW was $6.72 \mathrm{~g}(2.3 \%)$ for every $\mathrm{Mg} \mathrm{ha}^{-1}$ of applied gypsum (Figure 3). Although the soil exhibited adequate physical characteristics (BERTOLLO, 2014), chisel plowing may have favored water infiltration through the soil profile (CAMARA; KLEIN, 2005) and the vertical displacement of $\mathrm{S}_{-} \mathrm{SO}_{4}^{2-}$ from gypsum dissolution, thus increasing the availability of the nutrient in the soil and the absorption by corn (MASCHIETTO, 2009). When gypsum was not applied (zero dose), yield and TSW values for the chisel plowing treatment were lower than those for the plowing+harrowing treatments and continuous NTS, and they were higher at a dose of $6 \mathrm{Mg} \mathrm{ha}^{-1}$ of gypsum (Figure 2B and Figure 3).

In the second corn crop (2012/2013 crop year) the addition of gypsum increased grain yield by $205 \mathrm{~kg}$ $\mathrm{ha}^{-1}(2.1 \%)$ for every $\mathrm{Mg} \mathrm{ha}^{-1}$ of gypsum applied to the soil surface, according to the angular coefficient of the first-degree linear regression $(p=0.0303)$ (Figure 2B). This shows that the improvement of corn grain yield by the addition of gypsum is greater than that of soybean grain yield. Corn, like other Gramineae crops, is more responsive to increased $\mathrm{S}_{-} \mathrm{SO}_{4}{ }^{2-}$ content and the Ca:M gratin in the soil than soybean (RHEINHEIMER et al., 2005). Gramineae 
crops, in general, exhibit a lower capacity for root exchange cations than Leguminosae crops do and are therefore less efficient in absorbing divalent ions, such as $\mathrm{SO}_{4}{ }^{2-}$ and $\mathrm{Ca}^{2+}$ (MASCHIETTO, 2009). Fancelli (2010) reported that corn crops require between 3.0 and $3.5 \mathrm{~kg} \mathrm{ha}^{-1}$ of sulfur for everyt on of grain produced. Soils with an $\mathrm{S}_{-} \mathrm{SO}_{4}{ }^{2-}$ content lower than $10 \mathrm{mg} \mathrm{dm}^{-3}$ (extracted with calcium phosphate) are considered to be sulfur deficient, which limits corn yield.

Figure 3. Thousand-seed weight (TSW) of corn (2010/2011 harvest)according to gypsum dose applied to the soil surface andmechanical intervention. Frederico Westphalen, RS, 2014.

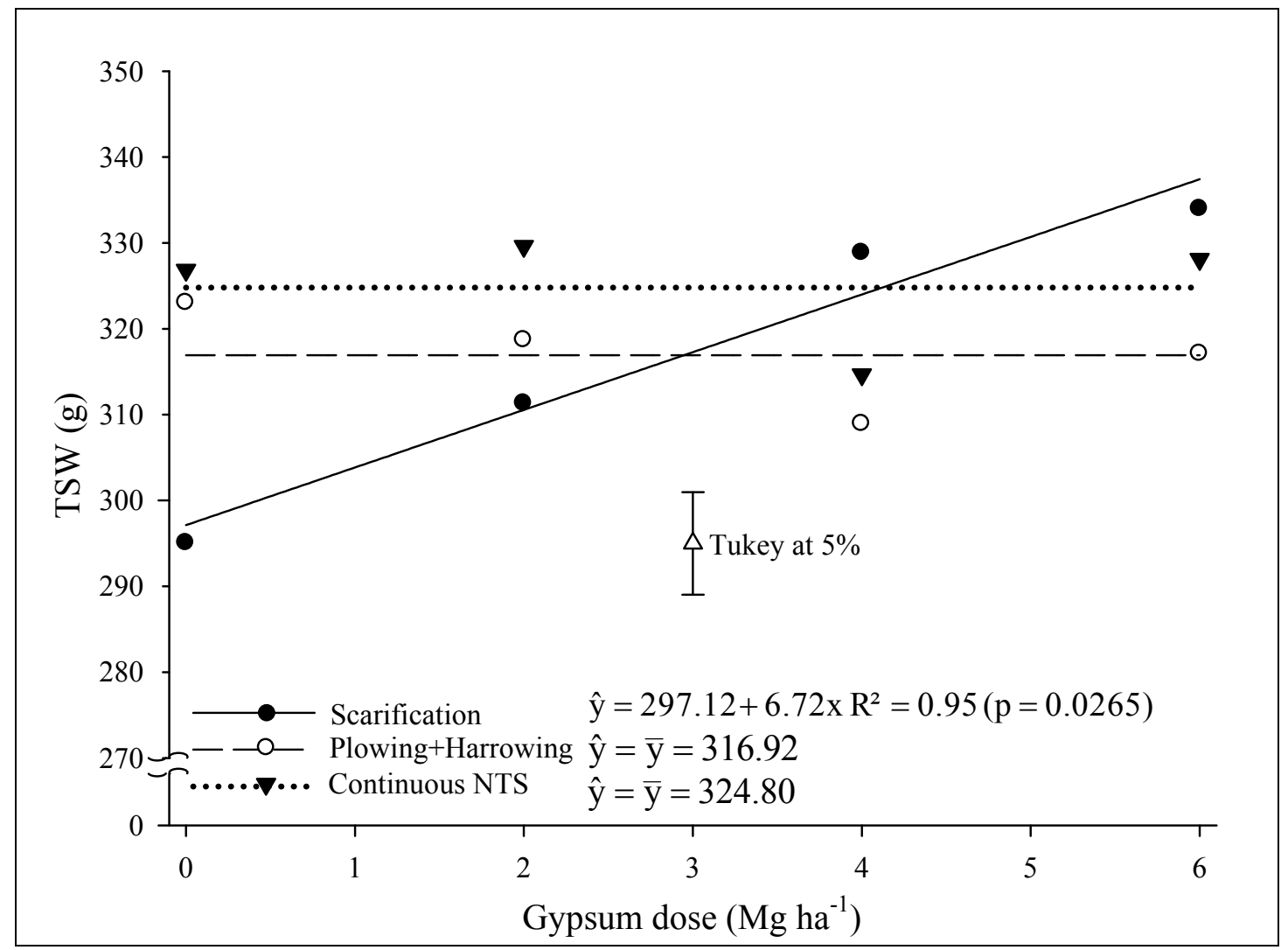

\section{Conclusions}

This study found that:

The mechanical interventions of soil plowing+harrowing or chisel plowing in an area und era continuous no-tillage system did not affect the grain yield and yield components of soybean culture, regardless of gypsum dose.

The corn crop was more responsive than the soybean crop to gypsum and was affected by the mechanical interventions conducted in the areas of continuous no-tillage cultivation.

\section{References}

BERTOLLO, A. M. Propriedades físicas de um Latossolo após calagem, gessagem, em manejos de solo. 2014. Dissertação (Mestrado em Agronomia) - Universidade Federal de Santa Maria, Frederico Westphalen.

CAIRES, E. F.; CHURKA, S.; GARBUIO, F. J.; FERRARI, R. A.; MORGANO, M. A. Soybean yield and quality as a function of lime and gypsum applications. Scientia Agricola, Piracicaba, v. 63, n. 4, p. 370-379, 2006.

CAMARA, R. K.; KLEIN, V. A. Escarificação em plantio direto como técnica de conservação do solo e da água. Revista Brasileira da Ciência do Solo, Viçosa, MG, v. 29, n. 5, p. 789-796, 2005. 
COLLARES, G. L.; REINERT, D. J.; REICHERT, J. M.; KAISER, D. R. Compactação de um Latossolo induzida pelo tráfego de máquinas e sua relação com o crescimento e produtividade de feijão e trigo. Revista Brasileira de Ciência do Solo, Viçosa, MG, v. 32, n. 3, p. 933-942, 2008.

Qualidade física do solo na produtividade da cultura do feijoeiro num Argissolo. Pesquisa Agropecuária Brasileira, Brasília, v. 41, n. 11, p. 16631674, 2006.

CRUZ, C. D. Programa Genes: biometria. Viçosa: Editora UFV, 2006. 382 p.

CUSTÓDIO, D. P.; OLIVEIRA, I. P.; COSTA, K. A. P.; SANTOS, R. S. M.; FARIA, C. D. Avaliação do gesso no desenvolvimento e produção do capim-Tanzânia. Ciência Animal Brasileira, Goiânia, v. 6, n. 1, p. 27-34, 2005.

DRESCHER, M. S.; ELTZ, F. L. F.; DENARDIN, J. D.; FAGANELLO, A. Persistência do efeito de intervenções mecânicas para a descompactação de solo sob plantio direto. Revista Brasileira de Ciência do Solo, Viçosa, MG, v. 35, n. 5, p. 1713-1722, 2011.

EMPRESA BRASILEIRA DE PESQUISA AGROPECUÁRIA - EMBRAPA. Sistema brasileiro de classificação de solos. 3. ed. Brasília: Embrapa Solos, $2013.353 \mathrm{p}$.

EPSTEIN, E.; BLOOM, A. Nutrição mineral de plantas: princípios e perspectivas. 2. ed. Londrina: Planta, 2006. $401 \mathrm{p}$.

FANCELLI, A. L. Boas práticas para uso eficiente de fertilizantes na cultura do milho. Piracicaba: IPNI, 2010. 16 p. (Informações Agronômicas, n. 131).

MASCHIETTO, E. H. G. Gesso agrícola na produção de milho e soja em solo de alta fertilidade e baixa acidez em subsuperficie em plantio direto. 2009. Dissertação (Mestrado em Agronomia) - Universidade Estadual de Ponta Grossa, Ponta Grossa.

MEDA, A. R.; PAVAN, M. A.; MIYAZAWA, M.; CASSIOLATO, M. E. Plantas invasoras para melhorar a eficiência da calagem na correção da acidez subsuperficial do solo. Revista Brasileira de Ciência do Solo, Viçosa, MG, v. 26, n. 3, p. 647-654, 2002.

MODA, L. R.; BORGES, B. M. M. N.; FLORES, R. A.; SANTOS, C. R.; PRADO, R. de M.; SOUSA, J. I de. Gessagem na cultura da soja no sistema de plantio direto com e sem adubação potássica. Revista Agroambiente, Boa Vista, v. 7, n. 2, p. 129-135, 2013.

MORENO, J. A. Clima do Rio Grande do Sul. Porto Alegre: Secretaria de Agricultura, 1961. 42 p.
NEIS, L.; PAULINO, H. B.; SOUZA, E. D.; REIS, E. F.; PINTO, F. A. Gesso agrícola e rendimento de grãos de soja na região do sudoeste de Goias. Revista Brasileira de Ciência do Solo, Viçosa, MG, v. 34, n. 2, p. 409-416, 2010.

RAMPIM, L.; LANA, M. C.; FRANDOLOSO, J. F.; FONTANIVA, S. Atributos químico do solo e resposta do trigo e da soja ao gesso em semeadura direta. Revista Brasileira de Ciência do Solo, Viçosa, MG, v. 35, n. 5, p. 1687-1698, 2011.

RHEINHEIMER, D. S.; RASCHE, J. W. A.; OSORIO FILHO, B. D.; SILVA, L. S.; BORTOLUZZI, E. C. Resposta de culturas à aplicação de enxofre e a teores de sulfato no solo de textura arenosa sob plantio direto. Ciência Rural, Santa Maria, v. 35, n. 3, p. 562-569, 2005.

SCHLINDWEIN, J. A.; BORTOLON, L.; FIORELIPEREIRA, E. C.; BORTOLON, E. S. O.; GIANELLO, C. Phosphorus and potassium fertilization in no till Southern Brazilian soils. Agricultural Sciences, Dois Irmãos, v. 4, n. 12, p. 39-49, 2013.

SOIL SURVEY STAFF. Keys to soil taxonomy. 11. ed. Washington, DC: USDA/NRCS, 2010. 372 p.

SORATTO, R. P.; CRUSCIOL, C. A. C. Produção de fitomassa e acúmulo de nutrientes pela aveia preta em função da aplicação de calcário e gesso em superfície na implantação do sistema plantio direto. Ciência Rural, Santa Maria, v. 38, n. 4, p. 928-935, 2008.

SORATTO, R. P.; CRUSCIOL, C. A. C.; MELLO, F. F. C. Componentes de produção e produtividade de arroz e feijão em função de calcário e gesso aplicados na superfície do solo. Bragantia, Campinas, v. 69, n. 4, p. 965-974, 2010.

SOUZA, F. R.; ROSA JUNIOR, E. J.; FIETZ, C. R.; BERGAMIN, A. C.; ROSA, Y. B. C.; ZEVIANI, W. M. Efeito do gesso nas propriedades químicas do solo sob dois sistemas de manejo. Semina: Ciências Agrárias, Londrina, v. 33, n. 5, p. 1717-1732, 2012.

SOUZA, F. R.; ROSA JUNIOR, E. J.; FIETZ, C. R.; BERGAMIN, A. C.; VENTUROSO, L. R.; ROSA, Y. B. C. J. Atributos físicos e desempenho agronômico da cultura da soja em um Latossolo Vermelho distroférrico submetido a dois sistemas de manejos. Ciência Agrotécnica, Lavras, v. 34, n. 6, p. 1357-1364, 2010.

TRINDADE, B. S. Atributos químicos do solo e a produtividade de grãos afetados pelo gesso agrícola. 2013. Dissertação (Mestrado em Ciência do Solo) Universidade Federal de Santa Maria, Santa Maria, RS. 